CONTRIBUICG̃O ȦS MEMÓRIAS

$A C A D \hat{E} M I C A S$

\title{
História do Hino Acadêmico
}

\section{Carlos Penteado de Rezende}

Antigo aluno da Faculdade de Direito da Universidade de S. Paulo e membro do Instituto Histórico e Geográfico de São Paulo.

\section{Antecedentes}

Em março de 1828, o antigo e pacato convento dos franciscanos da cidade de São Paulo viu-se transformado em instituição de ensino oficial do nascente Império brasileiro. A partir daqueles dias, transmudou-se por completo a rotina do convento: pelos corredores e salóes mergulhados na penumbra, e pelo pátio taciturno, não mais desfilaram sombras de frades desfiando rosários, ou murmurinhando páginas do breviário. Os poucos e humildes fradinhos do vasto casarão foram substituídos por vultos solenes de professôres carrancudos e por um magote de moços ativos e esperançosos. No pátio rodeado de arcarias, outrora silente, abandonado, passaram a ressoar inusitadas e alegres vozes juvenis.

No velho ambiente, todo espiritual, tinha início a formação de uma alma nova, também imbuída de espiritualidade. Nascia para o Brasil a Academia de Direito do Largo de São Francisco, destinada a formar gerações e gerações de advogados, professôres, políticos, magistrados, administradores, diplomatas, poetas, jornalistas, escritores e artistas.

Ora, por aquêle tempo, na distante e atrazada Vila de São Carlos, hoje Campinas, vivia um professor de música, 
chamado Manoel José Gomes. ${ }^{1}$ Enérgico, varonil, foi homem para casar várias vêzes e ter aí duas dúzias e tanto de filhos. Realista, impregnado de senso prático, a cada um de seus descendentes ensinava uma profissão com que fôsse capaz mais tarde de se encaminhar na vida. Um dêles teve vocação para sacerdote. Todavia, coisa com que o modesto Maneco Músico nem por sombra sonhou foi ter um filho doutor. Ele era um artista, ambicionava no máximo que alguns de seus rebentos também se destacassem como artistas. Mas fazer de um dêles um bacharel em direito, um magistrado, um lente - não! Idéias dêsse gênero êle não as tinha. Nem recursos para custear um capricho tal. Para que, se na São Carlos daquele tempo êle ganhava o suficiente para viver, desfrutava de prestígio social e era, no setor da música, como professor e regente de banda, a primeira figura da localidade? Por todos êsses motivos, também jamais lhe passaria pela cabeça que um de seus filhos prediletos viesse a ter um dia o nome para sempre ligado, indestrutivelmente, à gloriosa história da Academia de Direito paulistana. Mas foi o que aconteceu.

Antônio Carlos Gomes, vindo ao mundo aos 11 de julho de 1836, fruto dos amores ardentes do quarentão Maneco Músico e da jovem e bela cabocla D. Fabiana Maria Jaguary Cardoso, teria de cumprir o destino com que seu pai não sonhara.

Tonico, como era chamado em família, cresceu desenvolto. Frequentou a escola particular do mestre João

(1) Antônio C. Cesar, "Manoel José Gomes", in Diário de Campinas, n.० 6.873, de 19 de fevereiro de 1899. Benedito Otávio, "Antônio Carlos Gomes - Notas Para um Estudo Biográfico", in Revista do Centro de Ciências, Letras e Artes de Campinas, 1916, n.0 45, pgs. 39-64. Dr. Odécio de Camargo, "Maneco Músico", in Revista do Centro de C. L. e Artes, Campinas, 1936, n.o 56, pgs. 23-34. Arlindo Gomes, "Campinas, Sua fundação e sua História Musical", in Revista Brasileira de Música, 1936, vol. III $3 .^{\circ}$ e $4 .^{\circ}$ fasc., pgs. 490-495. Pelagio Lobo, "Os Gomes de Campinas", in Correio Paulistano, 6 de fevereiro de 1949 . 
Batista Alves de Souza, por antonomásia João Coração, onde aprendeu a ler, escrever e cantar a taboada à moda do tempo, e provàvelmente tomou conhecimento da existência das santas-luzias e das varas de marmelo. . ${ }^{2}$.

Era muito menino, tinha apenas oito anos, quando sua mãe apareceu assassinada a tiros e facadas no "trilho de um brejal". O misterioso homicídio (até hoje sem explicação segura) parece, segundo Benedito Otávio, haver marcado fundo a sensibilidade da criança.

Não se perturbou, porém, com os acontecimentos o rígido Manoel José Gomes, ao que tudo leva a crer inocente no caso: prosseguiu dando suas aulas de música e ensaiando a banda. Dos seus numerosos filhos, os únicos que provinham de D. Fabiana, ou sejam, José Pedro de Sant'Ana Gomes (Juca Músico) e Carlos Gomes, eram objeto do seu desvelo e também da sua severidade. Pretendia fazer dêles artistas às direitas. Em 1846, já participavam os dois meninos da banda musical e tiveram a satisfação de tocar diante de D. Pedro II, por ocasião da visita que êste fêz à já então cidade de Campinas.

Por vêzes, Maneco Músico aceitava serviços fora da cidade e levava os filhos. "( . . ) E referem que era engraçado ver-se o Juca engarupado com o Tonico, aquêle com o flautim à cintura, e êste conduzindo as músicas, atravessarem a cidade em demanda da estrada", conforme lembrou Antônio Cerqueira Cesar.

Bons tempos aquêles, de estudos, sonhos e trabalhos, com horas também para devaneios e molecagens com os amigos pelos campos próximos e pelas ruas desertas, onde antigos muros de taipa cercavam quintais cheios de árvores frondosas. 3

(2) Vicente Melillo, "A Instrução em Campinas", in Almanaque Histórico e Estatístico de Campinas, 1912, pg. 78.

(3) Cf. carta de Carlos Gomes a José Emydio Ramos Júnior, publicada por Sílio Bocanera Júnior, in "Um Artista Brasileiro", Bahia, 1913, pgs. 224-231. 
Na Semana Santa, as cerimônias na Matriz, com a preparada orquestra do pai a dar a nota _- o pai de óculos brancos, trajando famosa "casaca cor de rapé com botões amarelos". Nessas ocasiões, Tonico, dotado de excelente voz, participava do côro. Ao seu lado, cantando e marcando o compasso, se postava Américo de Campos, amigo constante, que foi depois bacharel em direito. ${ }^{4}$

Em seguida, vinha a procissão da Sexta-feira da Paixão, com a Verônica de negro a entoar o seu lamento junto à multidão respeitosa e comovida; no Sábado de Aleluia, o Judas dependurado em qualquer pau, a excitar a ira da garotada...

Em 1854, uma festa do Divino que marcou época, pois foi a derradeira vez em que se apresentaram cavalhadas na cidade. ${ }^{5}$

Nessa fase, o Tonico já ganhava a vida lecionando canto e piano pelas famílias campineiras, e igualmente em fazendas patriarcais dos arredores.

"A sua mocidade - conforme testemunhou Quirino dos Santos - correu como um pesadelo febril: estreiteza dos bens de fortuna, abundância enorme de aspirações, de desejos insaciáveis, de ideais indefinidos"

Outro autor pergunta: "Quem se recordará dos tempos em que vagava pelas nossas ruas, cantarolando ̀̀ meia voz, gesticulando o compasso distraído e quase sonâmbulo, como se recordam alguns dos seus contemporâneos ( . ) ?" 6

Conta Luiz Guimarães Júnior, o primeiro biógrafo de Carlos Gomes, que Maneco Músico ficou algo desiludido com aquelas fantasias de se tornar compositor que passavam pela mente do Tonico, e por isso voltou sua atenção

(4) Carlos Penteado de Rezende, "Tradições Musicans da Faculdade de Direito de São Paulo", pgs. 115-119.

(5) Vicente Melillo, Almanaque citado na nota 2, pg. 99.

(6) José de Campos Novais, reproduzido por Sílio Bocanera Junior, obr. cit. na nota 3, pg. 225. 
para Sant'Ana Gomes, que de fato se esmerou no estudo e chegou a ser um grande violinista.

Mas não havia no mundo fôrça capaz de impedir Tonico de ser um compositor. Pelo contrário, tudo o favorecia. Aos poucos, o seu talento se fazia renomado em Campinas. Bonito moço moreno, de maneiras francas e viris, havia mais de um motivo para dêle gostarem os conterrâneos. O seu círculo de admiradores, de amigos, aumentava sempre.

Uma das famílias que frequentava era a do Conselheiro Albino José Barbosa de Oliveira, que possuía fazendas nas cercanias de Campinas e ali por vêzes passava períodos de férias com os seus. Em 1855, cedeu o Conselheiro Albino a sua casa na cidade ao médico dinamarquês dr. Teodoro Langaard, com a condição de, quando viesse da Côrte, residir no lar do facultativo. O dr. Langaard, conhecedor de música, logo adivinhou as aptidões do Tonico e parece ter sido um dos primeiros a incitá-lo a ir estudar no Rio de Janeiro. ${ }^{7}$

Em 1856, arribou a Campinas, a negócios, um vendedor ambulante de jóias e pratarias, que era por igual musicista. Henrique Luiz Levy, israelita natural da AlsaciaLorena, tinha então vinte e sete anos. Como em Campinas não houvesse hoteis, hospedou-se êle. onde? Em casa de Manoel José Gomes. E sem tirte nem guarte ficou amigo do Tonico, com o qual vivia a fazer duetos, êle na clarineta, Tonico ao piano. Levy foi um dos que aconse. lhou Maneco Músico a mandar o filho para a Côrte. ${ }^{8}$

Carlos Gomes e seu mano Juca tiveram ainda a sorte de conviver debaixo do mesmo teto, durante meses a fio, por volta de 1859, com um autêntico virtuose, um daqueles

(7) Cons. Albino José Barbosa de Oliveira, "Memórias de um Magistrado do Império", pg. 238. Rodrigo Otávio, "Minhas Memórias dos Outros", 3." Serie, pg. 13.

(8) Cf. carta de Henrique Luiz Levy, reproduzida por Sílio Bocanera Júnior, obr. cit., pgs. 303-305. Carlos Penteado de Rezende, obr. cit., pgs. 104 e segs. 
meninos prodígios que na distante Europa provocavam o delírio das platéias cultas. Violinista exímio, discípulo de Alard no Conservatório de Paris, Paul Julien havia percorrido com êxito vários países da Europa e das Américas, antes de ir pedir pousada ao modesto Maneco Músico em Campinas. Contava então Julien menos de vinte anos de idade. 0 seu talento, a sua experiência internacional, e por certo as animadas prosas em família, com a evocação circunstanciada de teatros, conservatórios e artistas europeus, devem ter calado fundo nos dois irmãos Juca e Tonico, estimulando-os a sonhos e concepções mais arrojadas. Julien, segundo Cernicchiaro, encorajou Carlos Gomes a realizar o seu ideal de compositor. ${ }^{9}$

As primeiras composições conhecidas do Tonico, em Campinas, foram as seguintes:

"Uma Paixão Amorosa" - recitativo, dedicada a seu amigo José Emídio Ramos Júnior.

"Parada e Dobrado sôbre um Motivo do Trovador". Para Banda Militar. Data: Campinas, 20 de agôsto de 1856.

"A Rainha das Flores" - valsa.

"Bela Ninfa de Minh'Alma" - romance sentimental, poesia de Antonio Alexandrino.

"A Cayumba - Dança dos Negros, música original e de um gosto todo novo para piano".

"Missa de São Sebastião — Dedicada a seu amigo Levy (1856).

"Fantasia sôbre o romance Alta noite" - para clarineta.

Além de outras, que se perderam, ou de que se não tem memória.

A espontaneidade das primícias musicais de Carlos Gomes - inclusive aquela misteriosa dança dos negros $\boldsymbol{A}$ Cayumba, peça até hoje extraviada - repelem com van-

(9) Vincenzo Cernicchiaro, "Storia della Musica Nel Brasile" (Milano, 1926) pgs. 352 e 467. Carlos Penteado de Rezende, obr. cit. pgs. 132-134. 
tagem a afirmação posterior, bastante pretensiosa, do Professor Luigi Chiafarelli, de que o Brasil era "uma província musical da Itália". ${ }^{10}$ Engano do emérito professor. No Brasil Imperial amava-se por tôda a parte a música italiana. Mas a nossa terra tinha seiva própria, tinha fôrça, tinha originalidade. $E$ aquilo que estava latente nas fibras da raça, enquanto nos salões e nos teatros se fazia e se ouvia música italiana (e também música de outras origens, é evidente) viria um dia à tona para se impor definitivamente no concerto dos povos: o nacionalismo musical brasileiro.

Assim vivia Carlos Gomes em Campinas, a cumprir as suas obrigações, a sonhar e a compor. O pai precisava dêle na orquestra e o moço artista, cioso dos seus deveres, fundamente ligado ao seu meio, nem por sombras imaginava poder um dia escapar da tutela paterna para ser alguém no mundo da Arte, sòzinho.

Não obstante, já o seu nome repercutira em mais de um ponto da antiga Província de São Paulo, talvez mesmo fora. Na própria Capital, aos 14 de fevereiro de 1857, o "Correio Paulistano" publicara, a pedidos, extensa e elogiosa carta a respeito dêle, vinda de Campinas. $\mathrm{E}$ em junho e julho daquele ano, anúncios de três composições do Tonico (uma delas era "A Cayumba"), à venda na tipografia do jornal.

Raros artistas do tempo mereceriam publicidade assim natural e graciosa. Aliás, não havia muitos na Província que se destacassem: em Itu, Elias Álvares Lobo; em Santos, a familia de Luiz Arlindo da Trindade; em Parnaíba, Vicente Procópio; em Amparo, Azarias Dias de Melo; em Mogi-Mirim, a família Corrêa do Lago; em Pindamonhangaba, o Capitão Benedito Gomes de Araujo; em São Paulo, o Padre Mamede José Gomes da Silva. E quem mais?

A Campinas, sem dúvida, chegavam os jornais da Côrte, com amplo noticiário sôbre o movimento político,

(10) "Carlos Gomes", conferência realizada em 1909 (Duprat e Cia. São Paulo). 
social e artístico do País. Não era, portanto, mistério para ninguém, que desde 1857 estivesse em funcionamento no Rio de Janeiro a Imperial Academia de Música e ópera Nacional, fundada pelo espanhol Don José Amat. Por sua vez, o "Correio Paulistano" dava notícias das ocorrências na acanhada Paulicéia de então, onde pontificavam, como soberanos incontestes, com a sua inteligência, malícia e graça naturais, os acadêmicos de direito.

\section{Alvorada}

Raiou por fim o dia fagueiro em que o Destino colocaria no caminho de Carlos Gomes um talismã poderoso, suscetivel de lhe descerrar as portas do futuro. Como num passe de mágica, surgiram-lhe pela frente os seus guias, os seus inspiradores, os videntes que o instigariam a abrir as asas para voejar no páramo das águias.

Foi isso possível graças à ação onímoda dos estudantes de direito, que se não contentavam de viver o ano inteiro, pacatamente, sob os céus da Paulicéia. Eis que as aulas da Academia se prolongavam de fevereiro até fins de outubro, com feriados costumeiros aos domingos e quintasfeiras. Outros dias de descanso só eram viáveis pelo Carnaval, Semana Santa, dias santos de guarda, e por ocasião de festejos cívicos determinados pelo Govêrno. Obrigatória era a frequência às aulas:" Quinze faltas sem causa, e quarenta ainda que justificadas, faziam perder o ano". ${ }^{11}$

Sempre sobrava tempo, todavia, para um passeio, uma excursão pelos arredores da Capital. Ponte Grande, Penha, Cantareira, Tatuapé, Freguezia do ó, Pinheiros, Santo Amaro, entre outros, eram sítios muito conhecidos e frequentados pelos acadêmicos.

Às vêzes, jornadeavam os moços para mais longe. Iam caçar em fazendas, assistir a festas em Pirapora ou São Miguel, por exemplo, ou então desciam a Serra do

(11) Spencer Vampré, "Memórias para a História da Academia de São Paulo", vol. 1. ${ }^{\circ}$, pgs. 38, 418-420. 
Mar, demandando os ares e horizontes oceânicos na Barra de Santos, como tudo se poderá verificar através das cartas de Álvares de Azevedo. Outros, de temperamento boêmio e errante, como um Fagundes Varela, zaranzavam a pé ou a cavalo pelos subúrbios. sonhando versos, bebidas aventuras.

Também à São Carlos de outrora, Campinas atual, se dirigiam os estudantes nas suas andanças de férias. Mais difícil se lhes antolhava essa viagem, a exigir dois ou três dias a cavalo, com despezas e cansaços extras. Alguns, porém, enfrentavam com prazer os percalços da estrada, pois tinham família lá.

Em 1859, achavam-se estudando na Academia de Direito os seguintes moços, naturais de Campinas: Francisco Quirino dos Santos, Manoel Ferraz de Campos Sales, Jorge Ludgero de Cerqueira Miranda, Luiz José de Melo e Oliveira, Cândido Ferreira da Silva Camargo. Também eram nesse tempo acadêmicos o bragantino Américo de Campos, que residiu longos anos em Campinas, e João Gabriel de Morais Navarro, de Mogi-Mirim, mas radicado na terra das Andorinhas.

Em 1858, voltara de São Paulo formado o campineiro João Ataliba Nogueira, mais tarde o ilustre Barão de Ataliba Nogueira, bom amigo e admirador fervoroso de Carlos Gomes.

Nada estranhável, por conseguinte, que na Semana Santa de 1859 aparecessem por Campinas vários acadêmicos de direito, sequiosos os da terra de envolverem os seus familiares numa teia carinhosa de gabolices e novidades, e os demais, apenas curiosos de conhecerem uma nova cidade. Guardaram as crônicas os nomes de alguns: Francisco Azarias de Queiroz Botelho, mineiro, cursando o quinto ano, que sôbre ter uma "bonita e simpática figura", era dos mais estimados da turma, com a vantagem apreciável de ser exímio musicista amador; Antônio Dias Novais, por igual quintanista, dado a frequentar altas rodas, o qual se casou ainda estudante - e contam que 
com presteza jamais vista - com uma bela sinhazinha da sociedade de Campinas; João Gabriel de Morais Navarro, já referido, bacharelando inteligente, orador fecundo e imaginoso. ${ }^{12}$

Logo ao chegarem à prazenteira cidade fundada'por Barreto Leme, souberam que no Sábado de Aleluia, 23 de abril de 1859, haveria um concerto no Teatro São Carlos. Fôra a notícia divulgada no domingo anterior pelo jornal "Aurora Campineira". Havia intensa curiosidade em tôrno do concerto, sucesso raro naqueles tempos. Ademais, ao que se sabe, era a primeira vez em que se apresentavam ao público, na condição de concertistas, os filhos do velho Maneco Músico.

Via-se, pelo programa anunciado, que a parte principal fôra confiada a José Pedro de Sant'Ana Gomes ao violino (rabeca), e a Henrique Luiz Levy na clarineta, figurando Antônio Carlos Gomes como acompanhante ao piano. Certo, pois o Tonico era antes compositor que virtuose. Por êsse motivo, havia sido incluída, da autoria dêle, uma Fantasia sôbre o romance Alta noite, que o amigo Levy se encarregou de executar no seu mavioso instrumento. ${ }^{13}$

Não nós diz a Históriá quais as pessoas presentes à reunião. Fácil, porém, supor que lá deveriam estar Manoel José Gomes, quem sabe o dr. Teodoro Langaard, alguns membros da conhecida familia Monteiro, de musicistas, o jovem bacharel Ataliba Nogueira, os estudantes de direito vindos de São Paulo.. E quem mais? Talvez algum amigo da família Corrêa do Lago, àquele tempo residindo em Mogi-Mirim. A jovem D. Ambrosina Corrêa do Lago, como era sabido, provocara os primeiros arroubos amorosos de Carlos Gomes. ${ }^{14}$

(12) Almeida Nogueira, "A Academia de São Paulo - Tradições e Reminiscências”. Quinta Série (S. Paulo, 1908), pgs. 170, 186, 200.

(13) Vincenzo Cernicchiaro, obr. cit. pgs. 350-351.

(14) D. Itala Gomes Vaz de Carvalho, "A vida de Carlos Gomes", 2. ${ }^{a}$ edição (A Noite Editora S.A., Rio de Janeiro), pgs. 61-62. 
Aplausos gerais coroaram a feliz estréia dos três artistas. Os mais ruidosos e calorosos devem ter partido de quem estava afeito àquele tipo de manifestação, ou sejam, os acadêmicos. Um dêles, Francisco Azarias de Queiroz Botelho, não se limitou às palmas precárias. Com a sua viva intuição musical, descobrira naquele meio uma estrela de primeira grandeza, adivinhara um gênio em botão: Carlos Gomes.

Nhô Tonico, o caipira de Campinas, deveria conhecer mais horizontes, ampliar seu campo de ação, ganhar experiência noutros ambientes. Daí o convite formulado por Queiroz Botelho para que o Tonico, com seu irmão Juca, não deixasse de, na primeira oportunidade, ir à Capital, afim de ali of erecer um concerto aos paulistanos. ${ }^{15}$

Como bons semeadores de idéias e iniciativas, finda a Semana Santa retiraram-se de Campinas os acadêmicos, rumo aos seus estudos e afazeres. Mas a semente por êles lançada lá ficou, a germinar, a estuar, em solo fecundo.

Aos 11 de julho de 1859 Antônio Carlos Gomes fêz anos, completando vinte e três anos de idade. Não podemos, hoje, por falta de elementos, conjeturar que relação houve entre o seu aniversário e a data alviçareira em que partiu para São Paulo.

A verdade é que, lá pelos dias 12 ou 13 de julho, os três mosqueteiros da Arte - Tonico, Juca e Levy - se achavam na estrada demandando as várzeas "ubi Piratininga fuit". Levy, como de hábito, viajava a negócios, e os dois mais moços, desfrutando-lhe a amizade e a experiência, em busca de um Ideal.

Nada leva a crer que os dois irmãos Gomes tenham em ocasiões anteriores a 1859 viajado para a Capital, como afirma D. Itala Gomes Vaz de Carvalho, baseada talvez na biografia de Luiz Guimarães Júnior. ${ }^{16}$ Não há, a êsse respeito, nenhum documento conhecido. Considerem-se, como fatôres adversos à tese, a severidade, as exigências

(15) Almeida Nogueira, obr. cit. Quinta Série, pg. 187.

(16) Obra citada, pgs. 36-37. 
de Maneco Músico em relação aos filhos e, sobretudo, a falta de recursos materiais dêstes. Além disso, no "Correio Paulistano", principal diário da época, não se encontra (entre os anos de 1854 a 1859) a menor menção a respeito da presença de Carlos Gomes em São Paúlo. Podemos, portanto, aceitar como verídico que sòmente em julho de 1859 veio o Tonico a conhecer a Paulicéia acadêmica.

\section{Protofonia}

Quizeram os fados, nos seus ocultos e sábios desígnios, que os viajantes arribassem à Capital justamente numa quadra das mais propícias.

Frequentava a Faculdade de Direito, dirigida naquele ano pelo grave e bondoso Padre Manoel Joaquim do Amaral Gurgel, uma plêiade numerosa de estudantes de subido talento, cujos nomes mais tarde ecoariam por todo o País.

E São Paulo, o velho burgo plasmado heròicamente pelos jesuitas, bandeirantes e capitães-generais, transfigurado no decorrer do século xIx em benévolo aprisco da mocidade estudiosa; São Paulo das várzeas ridentes, dos casarões sonolentos, das igrejas históricas. das ruas quietas por onde deslizavam frades, beatas de mantilha e negros; São Paulo conhecida por todos como cidade letárgica como que se metamorfoseara naquele mês de julho de 1859 em centro de alegria, entusiasmo e novidades.

Quais os motivos dessa inesperada, inhabitual transformação? Poucos, mas eficazes. No Teatro do Pátio do Colégio realizaram-se vários bailes de máscaras. Em terrenos baldios, instalaram-se, com seus bichos, palhaços, equilibristas e bandas de música, dois circos diferentes, aptos com o seu prestígio a provocarem aplausos e rivalidades, eis que um dêles provinha do estrangeiro. ${ }^{17}$ Por

(17) "Tudo fartou-se por muitos anos de cavalinhos, nigromâncias, pelóticas, dansas de corda etc. O caldo porém ia-se entornando. As duas companhias que aqui estiveram eram de nações diferentes: 
último, chegaram à Capital, quasi simultâneamente, musicistas de valor como os irmãos Gomes, Levy e o jovem compositor ituano Elias Álvares Lobo.

Tôdas essas notícias, veiculadas pelo "Correio Paulistano", repercutiam, é claro, nas "repúblicas", onde agrupados viviam os estudantes como senhores feudais em seus castelos.

Espraiavam-se as "repúblicas" por todos os cantos da Paulicéia. Havia-as, por exemplo, na rua da Tabatinguera, rua das Flores, rua da Palha, rua da Glória, rua da Constituição... Umas mais famosas que outras, conforme a reputação, o temperamento ou.. as façanhas de seus moradores. Sim, porque se determinados rapazes se dedicavam a preparar teses, discursos e artigos, a ler os clássicos ou os juristas, a meditar, outros de vida boêmia se distraiam com namoros, caçadas noturnas de cabritos, banhos em pêlo no Tamanduateí e serenatas...

"Repúblicas" havia de caráter regionalista, congregando moços provenientes apenas de certa província ou zona do País. Isso por uma questão de hábitos ou de afinidades.

Na rua de São José, atual Líbero Badaró, demorava uma sòmente de mineiros. Eram êles: João Pinto Moreira, natural de Caeté, talvez o melhor estudante da Academia; Francisco Azarias de Queiroz Botelho e Aureliano Augusto de Andrade. Outra "república", na parte baixa da mesma rua, abrigava acadêmicos nortistas: José Gonçalves da Silva (Cazuza) e Antero Simões da Silva Cuim Atuá, baianos; e Francisco Leite de Bittencourt Sampaio, sergipano.

Estas duas "repúblicas", sem o querer, entraram para a História, valorizando diante das gerações futuras o ambiente sadio e idealista que nelas reinava, e constituin-

uma nacional, outra estrangeira; isto bastava para originar partidos (. .). Questões, gritarias etc. houveram (sic) in magna quantitate". Americo Gitahy, in Revista Mensal do Ensaio Filosófico Paulistano, n.o 4, S. Paulo, Sabado, 30 de julho de 1859. 
do-se em exemplo e modêlo para tôdas as outras. A dos mineiros - lembrou Salvador de Mendonça - foi "a casa em que foi virtualmente morar Carlos Gomes ao chegar de Campinas com seu irmão ( . )" A dos nortistas notabilizava-se "por possuir um piano no qual o futuro Maestro escreveu as suas duas primeiras composições na Capital paulista, o "Hino Acadêmico" e a modinha "Tão longe de mim distante" 18

Amavam a música os estudantes, tanto ou mais que a própria carreira por êles escolhida. Tratava-se de uma dedicação espontânea, pois que nesse setor grandes atrativos não lhes poderia oferecer a cidade isolada no planalto. Muito raramente um concertista se animava a subir a serra a fim de se apresentar à platéia provinciana. No pequeno Teatro do Pátio do Colégio, em geral ocupado por companhias dramáticas, o mais que se ouvia eram surradas aberturas de óperas por uma orquestrinha mambembe. Durante a representação, os atores num momento ou noutro entoavam coplas, canções, modinhas, e às vêzes também árias e duetos de óperas.

Nos bailes, dansavam-se valsas, polcas, quadrilhas. . Habitualmente, ouvia-se também música nas igrejas, no decorrer de festejos populares e nos agradáveis serões familiares. Alguns colégios de crianças ensinavam música, piano e canto aos seus alunos. Loja especializada no ramo ainda não havia. Livros, partituras, métodos, compêndios, papel pautado, tudo isso era encontrado em casas comerciais, que ofereciam aos seus freguezes, de cambulhada, os mais diversos e disparatados artigos. Depósito de pianos apenas um fôra aberto na cidade, em 1857, pelo cidadão suisso Jean Jacques Oswald, que vendia e alugava instrumentos de procedência inglêsa e francesa, anunciando-os pelo "Correio Paulistano"

(18) Salvador de Mendonça, "Carlos Gomes Intimo", in Jornal do Comércio, Rio de Janeiro, 2 de julho de 1905. 
O estabelecimento de Oswald na rua da Casa Santa, a um passo da Academia, explica a presença de pianos nas "repúblicas", onde aliás se notavam violões, flautas, rabecas e solfas. Os estudantes não sòmente praticavam a música, como por igual escreviam sôbre a divina arte nos seus jornais e revistas. Quando a lua cheia prateava os horizontes, saíam com as suas capas pretas em serenatas - dulcíssimas, inolvidáveis serenatas - pelas ruas envoltas em farrapos de neblina e, além, pelas várzeas infindas.

"E Carlos Gomes chega nessa época feliz — conforme testemunhou o então calouro e poeta Francisco Quirino dos Santos. - "É um aventureiro, é um sertanejo. Mas vem com o prestígio enorme dos seus grandes olhos profundos, negros, misteriosos; da sua fronte rasgada e ampla; dos seus lábios francos e abertos por onde se escapam palavras de um timbre metálico, sons rudes e a risada argentina, despreocupada do homem que tem a alma nas mãos, como vulgarmente se diz.

“A presença é insinuante e como que se impõe desde logo à simpatia e à estima, ou antes à admiração.

"Chega e cativa desde logo a fulgurante plêiade de rapazes. Torna-se num instante o companheiro inseparável das reuniões, dos passeios, dos mil folguedos gentis. "Adoram-no todos.

"É aí que começa verdadeiramente a sua marcha triunfal pelo caminho dos grandes espíritos" 19

Com o seu porte sobranceiro, a cabeça leonina e os olhos coruscantes, o jovem compositor demonstrava ser de fato um predestinado, um eleito da Arte. Também o irmão Sant'Ana Gomes e o amigo Levy eram artistas. Porque motivo não se extasiaram com êstes os acadêmicos? Porque igualmente não foi objeto de entusiasmo o moço

(19) F. Quirino dos Santos, "A. Carlos Gomes", in Almanaque Literário de São Paulo para 1881" (José Maria Lisboa), pgs. 35 a 48. 
ituano Elias Álvares Lobo, cuja presença na Capital foi assinalada pelo "Correio Paulistano" aos 15 de julho de 1859, com a observação que seguia para a Côrte, onde ia apresentar a entendidos uma ópera dêle com versos de José de Alencar?

O ambiente, as circunstâncias, as notícias, tudo parecia preparado para fazer Carlos Gomes brilhar, assumir papel de primeiro plano, e provocar no caipira de Campinas mais fundos anseios de glória.

Aos 16 de julho (em seguida portanto à de Elias Lobo) dava o "Correio Paulistano" a primeira informação a respeito dos irmãos Gomes em São Paulo:

"Concerto musical - Acham-se nesta cidade os artistas José de Sant'Ana Gomes, e Antonio Carlos Gomes, naturais da cidade de Campinas, que se propõem oferecer ao público desta Capital um concerto de rabeca e piano. De hạ muito são conhecidos os nomes dêstes jovens brasileiros, que a seu próprio talento devem a perfeição a que têm atingido em seus respectivos instrumentos. Em um país onde a arte da música ainda não obteve um método de ensino correspondente às vocações e talentos que nele abundam, deve-se admirar e animar gênios, que vencendo os obstáculos que os cercam chegam ao ponto de levar o orgulho aos espíritos patrióticos.

"Os dous paulistas que ora se apresentam ao público desta cidade, estão neste caso. Seria impossível mostrar em uma notícia as dificuldades de execução que o senhor José de Sant'Ana Gromes consegue vencer nas quatro cordas de sua rabeca, assim como o gôsto e firmeza com que seu irmão o senhor Antônio Carlos Gomes o acompanha ao piano. Êste concêrto tornar-se-á verdadeiramente completo com a conhecida clarineta do senhor Henrique Luiz, q'em obsequio ao talento dos artistas brasileiros se oferece a confundir o doce som de seu instrumento com os da rabeca e piano". 


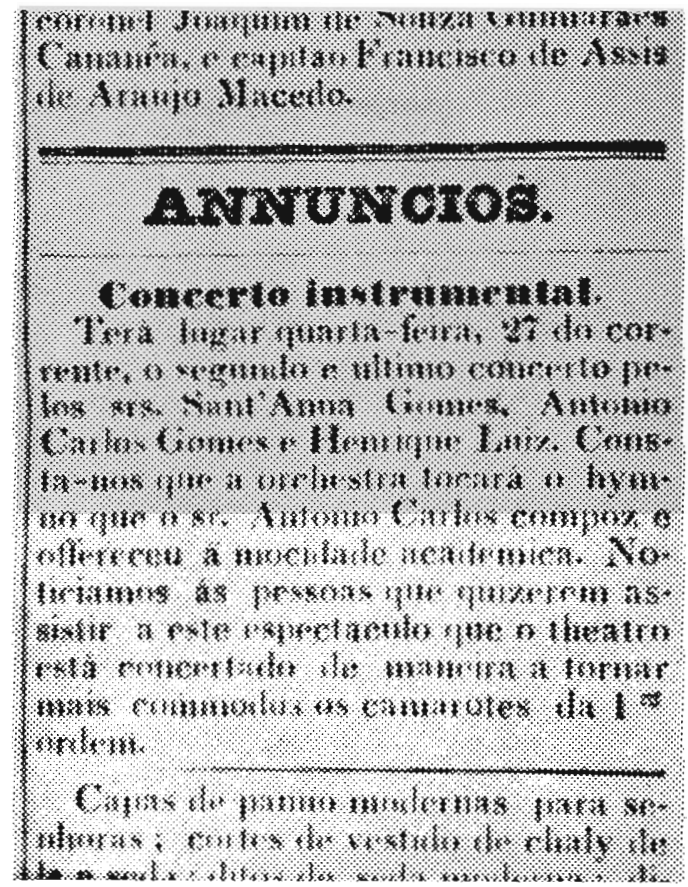

Notícia no jornal “A lei”, 25 de julho de 1.859 
No mesmo sábado em que saíu essa notícia, vinha na última página do jornal um curioso anúncio do "Circo Olímpico Equestre e Ginástico", companhia brasileira dirigida pelo senhor Custódio Amazonas. Compunha-se de vinte e sete pessoas, quarenta animais e uma bandinha com cinco figuras. Estava em São Paulo desde meados do mês anterior e realizava naquela tarde de 16 de julho a sua despedida.

Do espetáculo participava certo artista Antonio Carlos, cujo nome coincidia com o do Tonico, e que outro não era sinão Antonio Carlos do Carmo, exímio cavaleiro nascido na cidade da Franca e já famoso pelas suas incríveis habilidades na arriscada arte da equitação. As suas proezas assombrariam mais tarde platéias da Europa e dos Estados Unidos. ${ }^{20}$

Estrondosa decorreu essa despedida. Ou fôsse para prestigiar a empresa nacional diante de um outro circo estrangeiro do Sr. James P. Adams, recém-chegado, ou porque o programa de fato tivesse superado a expectativa, a verdade é que os espectadores se manifestaram ruidosamente, conforme registrou o "Correio Paulistano" de 19 de julho:

"O entusiasmo ( ) foi extraordinário, um número infinito de coroas, e outras ofertas foram oferecidas aos beneficiados; três poesias dedicadas aos artistas brasileiros foram recitadas, e no fim do espetáculo depois de chamados à cena várias vêzes, o povo saltou ao circo e seguido da música acompanhou os artistas à sua habitação, sendo

(20) Amigo de Carlos Gomes, êste Antônio Carlos do Carmo foi um dos raros brasileiros que, em 1870, tiveram a ventura de presenciar em Milão a estréia e o triunfo do Guarany. A respeito dêsse modesto, porém excepcional artista de circo, que honrou o nome do Brasil no estrangeiro, consultem-se: Dr. Plínio M. S. Ayrosa, "Traços da Vida de Antônio Carlos do Carmo", in Revista do Instituto Histórico e Geográfico de São Paulo, vol. 28.०, pgs. 51-64. Almeida Nogueira, obr. cit., Terceira Série (1908), pgs. 275-276. Tapajoz Gomes, "O Scala de Milão acolhe e Imortaliza O Guarany", in Revista Brasileira de Música, 1936, vol. III fasc. 2., pgs. 191-195. 
os jovens da companhia carregados pelo povo, durante o trajeto"

Carlos Gomes provàvelmente participou dessa alegria tôda com os seus amigos estudantes, embora caro lhe tivesse custado. Basta lembrar que arribou à Capital ai pelos dias 14 ou 15, e que o circo se despediu aos 16 de julho. Ora, si o Tonico foi vítima de um acidente no circo brasileiro, memorado pelos seus biógrafos, o caso deve ter ocorrido naquela tarde de sábado. Testemunha visual dos acontecimentos, o calouro Salvador de Mendonça escreveu anos depois:

"A primeira vez que vi Carlos Gomes fora do teatro foi em casa de Pinto Moreira; o jovem compositor chorava e tapava a boca com um lenço. Estou ainda a vê-lo com os seus belos cabelos negros, olhos rasos de lágrimas, e a seu lado o bom Francisco Azarias, acariciando-o com mimos quase maternos, o Azarias, alto, grande, barbadão, mas dono de um coração de ouro. Carlos Gomes fôra assistir a um espetáculo num circo de cavalinhos no Bexiga, no qual trabalhava a companhia de seu amigo Antonio Carlos do Carmo, e uma ferradura, desprendida na carreira por um dos cavalos, fôra, no meio das bancadas atopetadas de espectadores, escolher o jovem campineiro e partir-lhe um dente da frente. Por isso chorou como uma criança que era, e, louvado seja Deus, foi tôda a sua vida". ${ }^{21}$

Logo após êsse episódio do circo (que vai aqui referido com pormenores a título de curiosidade e confirmação de datas, já que as datas verdadeiras e documentadas, constantes dêste estudo, não conferem com as que veem nas biografias mais conhecidas de Carlos Gomes), logo após, um terceiranista de direito se debruçava à mesa de sua "república" e, puxando pela cabeça, escrevia extenso Folhetim para o jornal. Chamava-se o estudante Antonio Joaquim Macedo Soares. Era talentoso, cultivava

(21) Salvador de Mendonça, obr. cit. na nota 18. 
com apuro as letras e as artes e atingiu na vida pública, merecidamente, o alto posto de Ministro do Supremo Tribunal Federal. ${ }^{22}$ O seu trabalho, sob o título Revista Artística, saiu na primeira página do "Correio Paulistano" no dia 19 de julho de 1859.

$\mathrm{O}$ que há de importante nele é virem entrelaçados os nomes de três grandes artistas brasileiros. Por êsse Folhetim, ficamos sabendo que na noite de 15 de julho, num serão musical em casa do senhor Gomide, que residia na Rua da Freira, o ituano Elias Álvares Lobo, "em presença de algumas pessoas entendidas em música", exibiu a sua ópera "Noite de São João", ainda não instrumentada. Apenas esboçado se achava o acompanhamento para piano, e nem "eram completas as vozes dos apreciadores que se prestaram à prova dada pelo compositor"

A ópera de Elias Lobo era de fundo nacionalista, incluía um "coro dos caipiras" com acompanhamento obrigado de violas, e mereceu do ilustrado acadêmico Macedo Soares análise minuciosa, digna de um crítico musical, além de vibrantes elogios próprios de quem era moço e amava a arte de Bellini e Donizetti. Concluíu Macedo Soares:

"Estou que o sr. Elias Lobo ha de achar no Rio de Janeiro quem o anime à prosseguir na sua patriótica e excelente empresa. O belo, como a verdade, em tôda a parte aparece, porque brilha com a luz própria que lhe dá o gênio".

(Podemos perguntar, com tôda a isenção, si Carlos Gomes não teria estado presente a essa reunião artística do dia 15 de julho, deixando-se influenciar e estimular pelo ambiente, com repercussão posterior no seu estado de espírito e no seu futuro. Que os dois artistas, Lobo e Gomes se conheciam e se prezavam, prova-o o fato de em 1860 ,

(22) Salvador de Mendonça. idem, ibidem. Sacramento Blake, "Dicionário Bibliográfico Brasileiro", vol. 1.`, pgs. 197-199. Cel. Laurênio Lago, "Supremo Tribunal de Justiça e Supremo Tribunal Federal", pg. 155. 
no Rio de Janeiro, Carlos Gomes haver regido a "Noite de São João", que foi a primeira ópera nacional cantada). ${ }^{23}$

No seu Folhetim, Macedo Soares também distinguiu os irmãos Gomes, que ainda não haviam estreado em público, com palavras encomiásticas. Comparou Sant'Ana Gomes ao notável violinista português Sá Noronha, famoso na Europa e na América, o qual dera concertos em São Paulo em 1857. E gabou Carlos Gomes, "assaz conhecido pelo mundo musical no Rio de Janeiro e nesta Capital", autor de peças, entre elas a original Cayumba, que lhe davam "um lugar de honra entre os bons compositores brasiJeiros".

Tudo estava preparado para a estréia sensacional: elogios, notícias, calor, vibração na cidade. A expectativa era ainda aumentada por saber-se que em reuniões familiares Juca e Tonico já haviam demonstrado as suas notáveis aptidões.

E o que se esperava ocorreu. Na quinta-feira, 21 de julho (quinta-feira era feriado acadêmico, como sabemos) Carlos Gomes e Sant'Ana Gomes se apresentaram no Teatrinho do Pátio do Colégio, coadjuvados pelo amigo Levy. Casa repleta. Os estudantes de direito dando a nota, com a sua presença inteligente, sensivel, vibrátil. Rabeca, piano e clarineta, conjugados ou em solos, repercutindo uaviosamente pelo recinto histórico onde em 1822 o Padre Dr. Ildefonso Xavier Ferreira aclamara o primeiro rei do Brasil. A platéia atenta e enlevada. No final, como frizou o "Correio Paulistano", o que se viu foi um caloroso "entusiasmo que de todos os ângulos do teatro se manifes-

(23) No “Diário Popular", São Paulo, 28 de setembro de 1896, aparece um artigo sôbre Carlos Gomes, assinado L. V., que confirma as relações entre os dois compositores paulistas, em 1859 e posteriormente. Todavia, os dados e comentários do artigo precisam ser confrontados com outros, antes de aceitos. 
tou" Não será exagêro imaginar os concertistas ouvindo "Hurras!", "Bravos!" ou o velho grito "Tabatin!. . Tabatin!. Güera!..", partidos dos estudantes. ${ }^{24}$

Foi provàvelmente depois dêsse concerto, entre os dias 21 e 25 de julho, que Carlos Gomes compôs o Hino Acadêmico. Todos o procuravam para felicitá-lo. Nem mesmo na "república" da rua de São José viu-se o Nhô Tonico a salvo da admiração ruidosa dos cursistas de direito. Na residência do "Cazuza" reunia-se um grupo de rapazes talentosos, que levavam as horas a gastar espírito e a formular "as mais graciosas idéias", enquanto Carlos Gomes, ouvindo-os, debruçava-se sôbre o piano armário e corria os dedos nervosos pelas teclas.

"Glória, esperanças, coroas, sorrisos, aventuras... o que não sonha a cabeça de um estudante?!" - perguntou um dêles, Teodomiro Alves Pereira, no seu livro "Gennesco - Vida Academica". Pois tudo isso vinha à baila nas deliciosas Prosas de república. Prosas que duravam horas, varavam madrugada a dentro, embaladas às vêzes pelo toar preguiçoso de um violão, nas salas enfumaçadas pelos charutos. .

Prosas em que os estudantes, arautos inconscientes da nacionalidade, deixavam transparecer a voz da raça, aquilo que, a propósito de Castro Alves, descobriu Euclydes da Cunha: O eterno aspirar por um engrandecimento; $e$ uma afetividade indefinidamente avassaladora $e$ crescente. ${ }^{25}$

Foi de uma dessas prosas reconfortantes que se originou a lembrança do Hino Acadêmico. Bittencourt Sampaio, o poeta sergipano, de boa disposição para tudo, escreveu-lhe a letra e Carlos Gomes, ao piano, experimentando harmonias, compôs a música vibrante, que mais tarde Luiz Guimarães Júnior chamaria de "A Marselheza da Mocidade". O mesmo autor lembra que durante aquêles dias

(24) Vide Carlos Penteado de Rezende, obr. cit. pg. 96.

(25) Euclydes da Cunha, "Castro Alves e seu Tempo" - Discurso proferido no Centro Acadêmico Onze de Agôsto. Sem data. 
Carlos Gomes produziu ainda, "num arrebatador improviso, vários romances deliciosos", inclusive aquela modinha suavíssima intitulada Quem sabe?, conhecida no Brasil inteiro pelas suas primeiras palavras: "Tão longe de mim distante. . " 26

O Hino Acadêmico, dêsse- modo, representa aquela aspiração por um engrandecimento, adivinhada por Euclydes da Cunha; e a modinha "Quem Sabe?" a afetividade, a ternura brasileira. .

Teria havido antes de 1859 algum outro Hino, conhecido e cantado pelos estudantes? Sim, houve. Em 1843, por motivo de um incidente no teatro, vários acadêmicos foram recolhidos à cadeia no Largo de São Gonçalo e, no local, compuseram um hino apropriado às circunstâncias do momento, como então se dizia. Na mesma ocasião, o estudante Francisco Otaviano de Almeida Rosa escreveu a letra de um Hino Acadêmico, que foi muito cantado na época. ${ }^{27}$

Aliás, a idéia remota de um Hino Acadêmico deve ter-nos chegado de Coimbra, Heidelberg, ou outra vetusta universidade européia.

Aos 25 de julho de 1859, o jornal político A Lei estampava esta notícia: "Concerto instrumental - Terá lugar quarta-feira, 27 do corrente, o segundo e último concerto pelos srs. Sant'Ana Gomes, Antonio Carlos Gomes e Henrique Luiz. Consta-nos que a orquestra tocará o hino que o sr. Antonio Carlos compôs e ofereceu d̀ mocidade acadêmica"

Deduz-se, por conseguinte, que o Hino de Carlos Gomes foi composto antes dêsse dia 25 de julho.

Não podemos, com certeza absoluta, saber si se efetuou ou não na data prevista êsse segundo concerto, também noticiado pelo "Correio Paulistano". Teria sido transferido?

(26) L. Guimarães Junior, "A. Carlos Gomes-Perfil Biográfico". Rio de Janeiro, 1870. Pág. 24.

(27) Carlos Penteado de Rezende, obr. cit. pgs. 44-46. 


\section{THEATRO}

\section{Sabade 30 do ecrmat.}

Grakile a sartade divertionate lods en he

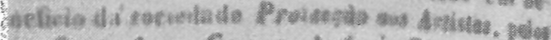

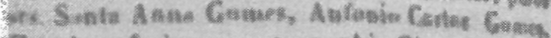

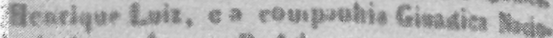

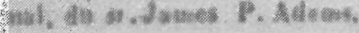

\section{regrenama. \\ $1 *$ * $37 \%$}

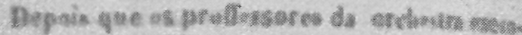

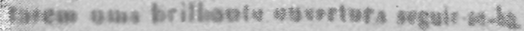

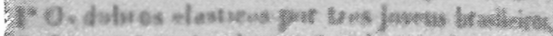

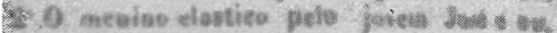
Eiras,

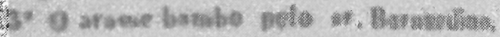

$$
2^{*} \text { psarn. }
$$

CONCEHTT.

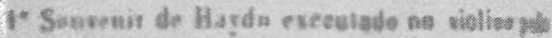
3.. Sagra A tand Gameas.

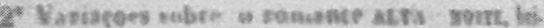

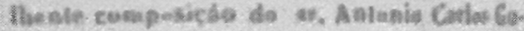

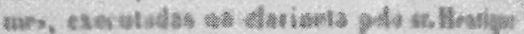
Laiz.

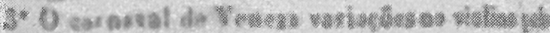

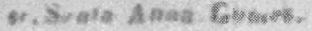

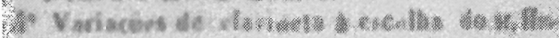
sigue Luiz.

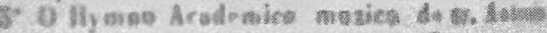

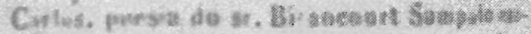

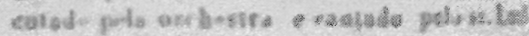

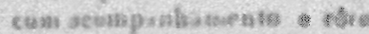

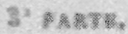

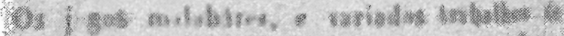

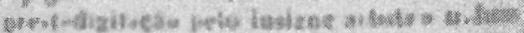

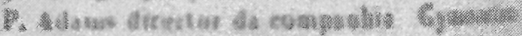
Wive enal.

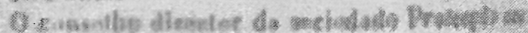

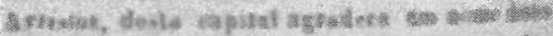

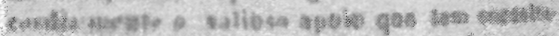

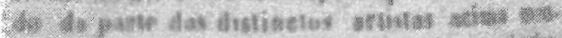

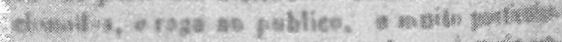

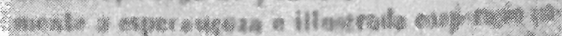

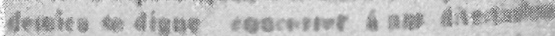

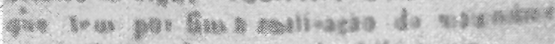

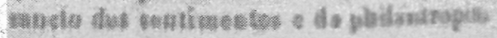

\section{Typ. Imparcial.}

Programa do espetáculo de apresentação do Hino Acadêmico. Publicado no "Correio Paulistano" de 29 e 30 de julho de 1.859 é agora, cem anos depois, exibido pela primeira vez à curiosidade dos estudiosos. 
A verdade é que a estréia do Hino Acadêmico foi num sábado, 30 de julho de 1859 , conforme programa impresso na última página do "Correio Paulistano". (Edições de 29 e 30 de julho). Organizaram os estudantes um "Grande e variado divertimento todo em benefício da sociedade Proteção aos Artistas", contando com a colaboração direta de Juca, Tonico, Levy e de alguns equilibristas do circo do sr. James P. Adams - já nessa semana denominado Companhia Ginástica Nacional.

Esteve à cunha o teatrinho do Pátio do Colégio e o objetivo filantrópico foi atingido: "O concerto rendeu $1: 200 \$ 000$, o que era muito para êsse tempo!" - lembrou Henrique Luiz Levy.

Incluía o programa duas composições de Carlos Gomes, as "Variações sôbre o romance Alta Noite", interpretadas por Levy na sua clarineta; e o Hino Acadêmico - executado pela orquestra e cantado pelo sr. Leal com acompanhamento e coro" Dêsse coro, é evidente, participaram os mais interessados naquilo tudo, ou sejam, os rapazes da Academia de Direito, consoante registrou Levy na sua carta conhecida.

$\mathrm{E}$ então, por todos os ângulos do acanhado recinto reboaram os versos famosos: ·

"Sois da pátria esperança fagueira

Branca nuvem de um roseo porvir;

Do futuro levais a bandeira,

Hasteada na frente a sorrir.

"Mocidade, eia avante, eia avante!

Que o Brasil sôbre vós ergue a fé;

Esse imenso colosso gigante

Trabalhae por erguê-lo de pé!"

Etc. Etc.

A comoção foi geral. O êxito, imediato, contagiante, eletrizante. O Hino Acadêmico de Carlos Gomes soou no teatro como si fôsse um clarim de conclamação às fileiras. 
Foi um rebate viril, congregando num só e inspirado canto os anseios dispersos da mocidade. Fez eco, que se transmitiu de geração em geração, decênios em fora, até chegar, puro, imaculado, aos dias agitados do século XX.

Tentaram outros compositores imitá-lo, ou superá-lo na preferência dos estudantes. Furtado Coelho em 1861, Brasílio Itiberê da Cunha em 1870, o maestro Orestes Bimboni em 1871, entre outros, compuzeram marchas e hinos dedicados aos acadêmicos. Em vão! Jamais conseguiram o que sòmente o gênio de Carlos Gomes logrou alcançar: inflamar ao extremo, às últimas consequências, o generoso coração da mocidade.

(Podemos também, a esta altura, indagar si o ituano Elias Álvares Lobo não teria por acaso presenciado os êxitos de Carlos Gomes em São Paulo, ou si partiu logo para o Rio de Janeiro, satisfeito com os elogios que na Paulicéia recebera. Como quer que seja, representou para os estudantes, naqueles dias, uma figura neutra, uma personalidade séria demais talvez, incapaz de excitar o ardor da juventude).

Ésse concerto trouxe para a vida do Tonico consequências ponderosas e definitivas. Ao que tudo leva a crer, foi após a sua realização que Carlos Gomes criou coragem para abrir as asas e sair, espaço em fora. Reunido com os estudantes numa "república", em meio à vibração geral, regada a champanha, versos e discursos, ouviu Tonico o conselho que já muitas vêzes recebera em Campinas: Vai para o Rio de Janeiro! E êle então se dispôs a partir. O episódio, tornado célebre graças à pena fantasiosa de Luiz Guimarães Júnior, revestiu-se de circunstâncias poéticas e heróicas.

Salvador de Mendonça, nas suas reminiscências, confirma o estímulo direto dado pelos acadêmicos: "Reuniuse o cenáculo e votou que Carlos Gomes seguisse para o Rio a estudar no Conservatório de Música. A resolução ia de encontro aos desejos de seu pai, que carecia de seus serviços na orquestra de Campinas; mas ainda assim pre- 
ras o outras muitas fasendas q' se vendem MUI TO BARATO.

\section{II ymuo academico.}

\section{POESIA DO SR. BITAMCOURT SAMPAIO.}

Musica do sr. dr. Antonio Carlos Gomes.

Esta bellissima composiça que tanto tem agradado a illustrado publico de S. Poulo, oebase á vendo em casa do sr. Henriquo Fox, rua do Rosario, à ID rs, o exemplar.

\section{Hotel

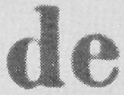 \\ France.}

Anúncio no "Correio Paulistano", 4 de setembro de 1.859 
valeceu a opinião do cenáculo. Entre várias cartas de recomendação que gente tão luzida podia fornecer, três foram as que mais lhe aproveitaram. Macedo Soares obteve uma carta de apresentação para a Sra. Condessa de Barral, escrita por Tell Ferrão (...). Eu dei-lhe outra para o meu conterrâneo Dr. Joaquim Manoel de Macedo. Francisco Azarias recomendou-o a um comerciante seu com-provinciano, (...)."

$\mathrm{E}$ assim, de improviso, inesperadamente, num abrir e fechar de olhos, o Nhô Tonico de Campinas, empurrado pelos estudantes (eia avante! eia avante!) largou as amarras que o prendiam a um passado estreito, sem possibilidades, e lá se foi, corajoso e palpitante, no encalço da Glória, que o esperava de braços abertos. Iniciou, então, no Rio de Janeiro, a escalada trabalhosa, cheia de sacrifícios, que o levaria, degrau a degrau, à Imortalidade. ${ }^{28}$

Já na Côrte, absorvido pelos seus sonhos e preocupações, não olvidou, porém, Carlos Gomes os amigos estudantes. Tanto isso é verdadeiro que, poucas semanas depois, já o Hino Acadêmico se achava impresso (revela o dr. Francisco Morato que pela Casa Arthur Napoleão) ${ }^{29}$ e era sem tardança enviado à Paulicéia.

(28) No livro "Tradições Musicais da Faculdade de Direito de São Paulo", o Autor dêste estudo, baseando-se em Hermes Vieira " $O$ Romance de Carlos Gomes" e Renato Almeida "História da Música Brasileira", aceitou a versão que pretende haver Carlos Gomes regressado a Campinas depois dos sucessos obtidos em São Paulo, para sòmente numa ulterior oportunidade fugir para o Rio de Janeiro. Melhor ponderado o assunto, e cotejadas as datas e documentos até agora conhecidos, quer-nos parecer que Carlos Gomes deve ter na realidade partido para o Rio de Janeiro logo após o êxito do Hino Acadêmico em São Paulo, talvez aos 31 de julho, ou começos de agôsto de 1859. Vide também nosso artigo "Um Centenário e Algumas Correções", in Suplemento Literário de "O Estado de São Paulo", 8 de agôsto de 1959.

(29) Dr. Francisco Morato, "O Hino Acadêmico", in Revista da Faculdade de Direito de São Paulo, vol. $33 .^{\circ}$, fasc. $1 .{ }^{\circ}$, janeiro-abril de 1937. 
Aos 4 de setembro de 1859, anunciava o "Correio Paulistano": "Hymno Academico" - Poesia do sr. Bittencourt Sampaio. Música do sr. dr. Antonio Carlos Gomes. Esta belíssima composição, que tanto tem agradado ao ilustrado público de S. Paulo, acha-se à venda em casa do sr. Henrique Fox, rua do Rosário, à $1 \$$ rs. o exemplar".

O melhor de tudo, não há dúvida, foi a ingenuidade de chamarem o Tonico de Sr. Dr. Antonio Carlos Gomes! Num país onde todo o mundo era doutor, inclusive os simples aprendizes de leis, o mocinho que compunha música como aquela tinha de ser forçosamente. doutor!

Já durante as semanas de agosto, e em setembro de 1859, era o Hino Acadêmico, a pedidos, cantado e tocado nas representações do Teatrinho do Páteo do Colégio. Propagava-se, dêsse modo, como um rastilho, a flama varonil daquela composição nascida numa "república", vivificada pelos mais límpidos e nobres ideais, batizada a seguir com a fibra e a paixão da mocidade e destinada a vencer as barreiras do Tempo.

$\mathrm{E}$ foi assim que o irrequieto filho do Maneco Músico de Campinas cumpriu o destino com que seu pai jamais sonhara. Carlos Gomes partiu, abriu azas, atravessou mares e continentes, criou obras primas, cobriu de glórias o nome de sua terra e de sua gente.

Mas deixou aqui em São Paulo - marco zero do seu destino e coração da nacionalidade - um facho que vive ardendo através das gerações na pira do velho convento franciscano: o Hino Acadêmico, protofonia de uma obra luminosa. 